Letter to the Editor

\title{
The phytochemical diversity and product quality of shea butter present confounding factors to product standardization in research
}

Sir,

Muoghalu et al, describe the anti-inflammatory activity of whole unrefined shea butter in an animal model. ${ }^{1}$ This study is important because shea butter extracts have promising characteristics for treating inflammatory disorders. However, the authors did not appropriately characterise the concentration of the specific bioactive compounds identified from their literature review prior to their in vivo studies. This lack of characterisation limits ability to extrapolate the important anti-inflammatory findings more broadly.

The anti-inflammatory triterpene phytosterols mentioned in Muoghalu et al, reside in the unsaponifiable fraction of shea butter, along with antioxidant compounds including lipophilic tocopherols and hydrophilic phenolic compounds such as catechins., ${ }^{2,3}$ Given that the unsaponfiable content of shea butter ranges so widely, mostly between 2 and 11 percent, and that outliers much higher than this range have been noted, it would have been useful for the authors to have assessed the actual content in these bioactive compounds as a basis for evaluating the bioactivity (therapeutic value) of the shea butter used in the experiment. ${ }^{4,5}$ As levels of triterpene phytosterols are posited to have been responsible for the anti-inflammatory effects of the shea butter, insufficient characterisation of these constituent compounds in the whole shea butter raises a number of issues linking bioactivities to the active constituents. ${ }^{6.7}$

This lack of characterisation illustrates an economic problem as well as an academic issue. Choosing from a diversity of phytochemical profiles based on geography, buyers may be expected to pay more for shea kernel and butter from specific provenances known to yield significantly higher levels of phytochemical compounds sought for specific product applications, including those with documented therapeutic effects. For example, a commercial skin care ingredient, consisting of an unsaponifiable-rich shea butter fraction, currently sells for US $\$ 470$ per kilogram, and is recommended for use in skincare formulations at just $1.5 \%{ }^{8}$ This product is almost certainly derived from shea butter of Nigerian origin, as suggested by its trade name, 'NG Shea Unsaponifiable' noting that $\mathrm{NG}$ is the international country code for Nigeria. However, Nigerian shea producers remain among the least remunerated across the region, due to reputational problems of product quality compounded a lack of producer awareness of product value as a function of its composition. $^{9}$

A series of analyses drawn from sets of geographicallylimited data suggest that the phytochemical diversity in shea butter is highly dependent on zone of origin. Future work is needed to determine the total lipid content, fatty acid profiles, and stearic-oleic-stearic (SOS) fatty acid content and unsaponifiables content characteristic of specific origins across the species range. ${ }^{4,5}$ These types of data would allow identification of shea tree populations that meet desired product phytochemical profile requirements.

Likewise, standardization of product quality according to standard quality parameters (free fatty acids, peroxide value) and proxies (moisture and insoluble impurities) would also have been important, since fatty acids broken down by rancidity are known to yield free radical compounds with cytotoxic properties specifically linked to the 'pathophysiology of aging' in the epidermis. ${ }^{10}$ In their quality analysis of Nigerian shea butter, Munir et al. found a free fatty 'acid value... [between] $8.42 \mathrm{mg} \mathrm{KOH} / \mathrm{g}$ and $3.36 \mathrm{mg} \mathrm{KOH} / \mathrm{g}$, (and a) peroxide value of (between) 15 $\mathrm{meq} / \mathrm{kg}$ and $9.40 \mathrm{meq} / \mathrm{kg}$ ' - the upper values of each parameter indicative of a degraded, rancid product. ${ }^{11}$

The results that Muoghalu et al, present are promising, but including the phytochemical characterisation of the raw materials used in the study would have allowed this important work to be extrapolated more broadly, and potentially applied to upgrade origin-specific market opportunities for rural shea producers. ${ }^{1}$

Eliot T. Masters*

Department of Applied Business, Nelson Marlborough Institute of Technology, Nelson, New Zealand

*Correspondence to Eliot T. Masters, E-mail: sheanut@gmail.com

\section{REFERENCES}

1. Muoghalu GU, Akah PA, Okoye TC, Ezenyi IC, Ibeneme S, Okoli CO. Anti-inflammatory activity of fatty extract of Vitalleria paradoxa Kernel (Shea butter) and pattern of its clinical use in arthritis in Enugu, South East Nigeria. Int J Basic Clin Pharmacol. 2018 Jan 20;5(6):2345-51. 
2. Maranz S, Wiesman Z. Influence of climate on the tocopherol content of shea butter. J Agr Food Chemist. 2004 May 19;52(10):2934-7.

3. Maranz S, Wiesman Z, Garti N. Phenolic constituents of shea (Vitellaria paradoxa) kernels. J Agr Food Chemist. 2003 Oct 8;51(21):6268-73.

4. Maranz S, Wiesman Z, Garti N. Bianchi. Vitellaria Database 1999-2004.

5. Di Vincenzo D, Maranz S, Serraiocco A, Vito R, Wiesman Z, Bianchi G. Regional variation in shea butter lipid and triterpene composition in four African countries. J Agr Food Chemist. 2005 Sep 21;53(19):7473-9.

6. Andersson, AC, Alander J. Shea Butter Extract for Bioactive Skin Care. Cosmetics \& Toiletries Research. 2015;130(6):18-25.

7. Akihisa T, Kojima N, Kikuchi T, Yasukawa K, Tokuda H, Masters ET, et al. Anti-inflammatory and chemopreventive effects of triterpene cinnamates and acetates from shea fat. J Oleo Scienc. 2010;59(6):27380 .
8. Sederma. NG SHEA Unsaponifiable. Product specification sheet; 2014:2.

9. Masters, E. Shea Value Chain Study Report to CRS. Report to CRS Nigeria. CRS: Abuja; 2017:100.

10. Stohs SJ. The role of free radicals in toxicity and disease. J Basic Clin Physiol Pharmacol. 1995;6(34):205-28.

11. Munir SM, Umaru M, Abdulrahman Z, Mohammed IA, Aliy AM, Salihu Y. Extraction and Characterization of Nigeria Shea Butter Oil. Mathematics and Education. JOSTMED (8).2012;2:66-73.

Cite this article as: Masters ET. The phytochemical diversity and product quality of shea butter present confounding factors to product standardization in research. Int J Basic Clin Pharmacol 2018;7:2070-1. 